\section{Ultrastructural histochemistry in biomedical research: Alive and kicking}

\author{
Manuela Malatesta \\ Department of Neurosciences, \\ Biomedicine and Movement Sciences, \\ University of Verona, Italy
}

\begin{abstract}
The high-resolution images provided by the electron microscopy has constituted a limitless source of information in any research field of life and materials science since the early Thirties of the last century. Browsing the scientific literature, electron microscopy was especially popular from the 1970 's to 80 's, whereas during the 90 's, with the advent of innovative molecular techniques, electron microscopy seemed to be downgraded to a subordinate role, as a merely descriptive technique. Ultrastructural histochemistry was crucial to promote the Renaissance of electron microscopy, when it became evident that a precise localization of molecules in the biological environment was necessary to fully understand their functional role. Nowadays, electron microscopy is still irreplaceable for ultrastructural morphology in basic and applied biomedical research, while the application of correlative light and electron microscopy and of refined ultrastructural histochemical techniques gives electron microscopy a central role in functional cell and tissue biology, as a really unique tool for high-resolution molecular biology in situ.
\end{abstract}

\section{Introduction}

Since the early Thirties of the last century, when the first electron microscope was built, the high-resolution images provided by this revolutionary instrument has constituted an inexhaustible source of information in any research field of both life science ${ }^{1}$ and materials science. ${ }^{2}$

The diffusion of commercial transmission electron microscopes and, afterward, of the scanning electron microscopes resulted, from the Fifties to the Seventies, in an extraordinary increase of studies aimed at describing the fine morphology of living or material structures, leading to a remarkable advancement of knowledge. At the same time, histochemical and immunohistochemical techniques, until then prerogative of light microscopy, were applied to electron microscopy, thus allowing the precise loca- tion of molecules in cell and tissue components by using electrondense markers. . $^{3-10}$

In the field of life science, since 1956 about 270,000 articles (96,000 on biomedical subjects) have been published where electron microscopy was used (source: Scopus database); out of them, more than 47,000 articles or reviews also contained histochemical data (about 44,000 on biomedicine, while 3000 only fall into the field of animal or plant biology). Looking at the distribution of published papers in this timespan (Figure 1), it is evident that electron microscopy was especially popular from the 1970 's to 1980 's, whereas during the Nineties, with the advent of innovative molecular techniques, electron microscopy seemed to be downgraded to a subordinate role as a merely descriptive technique, with a concomitant decrease in the number of published papers. However, when it became evident that a precise localization of molecules in the biological environment was necessary to understand their functional role, a sort of Renaissance of ultrastructural histochemistry took place, ${ }^{11-28}$ which has still been continuing during the last decade. ${ }^{29-41}$ In this regard, it is interesting to observe (Figure 1) that the articles containing histochemical and ultrastructural data became relatively frequent since the second half of the 1970's, progressively increased in the 1980's, to remain almost constant in their yearly number until now.

\section{May electron microscopy still make a relevant contribution to life sciences?}

In recent years, with the advent of the fluorescence super-resolution microscopy, the limit of optical resolution of light microscopy (about $250 \mathrm{~nm}$ ) was decreased to the 20-50 $\mathrm{nm}$ range, ${ }^{42-44}$ which enabled to examine cellular details at the nanoscale level, previously unattainable with light microscopes, and approaching the resolution of electron microscopy. ${ }^{45}$ In some authors' opinion, super-resolution microscopy "has the potential to replace conventional light microscopy in subcellular imaging questions as the dominant go-to technique", ${ }^{46}$ enjoying the benefit of the wide variety of available multicolor histochemical techniques. This even makes it questionable whether transmission electron microscopy (TEM) and scanning electron microscopy (SEM) may still make a relevant contribution to the studies in life science, especially in advanced research fields.

Electron microscopy techniques have been used for a variety of investigations in life science, and it would be very difficult to analyze in detail a so large number of
Correspondence: Manuela Malatesta, Department of Neurosciences, Biomedicine and Movement Sciences, University of Verona, Strada Le Grazie 8, I-37134 Verona, Italy.

Tel. +39.045.8027569

E-mail: manuela.malatesta@univr.it

Key words: Transmission electron microscopy; scanning electron microscopy; high resolution.

Received for publication: 25 October 2018.

Accepted for publication: 31 October 2018.

This work is licensed under a Creative Commons Attribution-NonCommercial 4.0 International License (CC BY-NC 4.0).

CC Copyright M. Malatesta, 2018

Licensee PAGEPress, Italy

European Journal of Histochemistry 2018; 62:2990 doi:10.4081/ejh.2018.2990

papers in the scientific literature, attempting to understand how electron microscopy was applied, and whether new fields of research may have born, especially in recent years. Thus, I decided to limit my survey to the articles published in the European Journal of Histochemistry, taken as an example of a purely histochemical journal that has traditionally been devoted to a wide assortment of subjects in biology and medicine, from functional cell and tissue biology in animals and plants, to cell differentiation and development, to the cellular basis of diseases.

Taking into account the articles published herein during the last decade, it is evident that many studies (on average $12 \%$, with an increase of about $4 \%$ in the last three years) either combined histochemical techniques at light microscopy with the high-resolution morphology provided by electron microscopy, or directly applied ultrastructural histochemistry.

The ultrastructural morphological approach at TEM has been widely used in basic and applied biomedical research for the study of different tissues under unperturbed or experimental conditions: tooth structure and repair; ${ }^{47,48}$ white adipose tissue classification; ${ }^{49,50}$ stem cells culture for reconstructive purpose; ${ }^{51,52}$ skeletal muscle features under experimental ${ }^{13,54}$ and pathological ${ }^{55,56}$ conditions; liver response to pretransplantation treatment; ${ }^{57}$ female reproductive organs ${ }^{58}$ and explanted oocytes for in vitro reproduction; 59,60 post-implant skin modification; ${ }^{61}$ autopsy myocardium for diagnostic purposes ${ }^{62}$.

Fine morphology at TEM has also been applied in cell ${ }^{63-67}$ and developmental biology, ${ }^{68-70}$ and was essential to describe the fine morphology of tissue and organs of differ- 
ent animal species..$^{71-74}$ In recent years, morphology at TEM proved to be crucial in nanomedicine to describe the interactions of nanoconstructs with different cell components. ${ }^{38,75}$ Finally, morphological analysis at TEM has been applied to reveal the structural preservation of explanted organs or tissues maintained in vitro in innovative fluidic systems. ${ }^{76}$ The three-dimensional ultrastructural morphology provided by SEM contributed to the detailed characterization of bone ${ }^{77}$ and adipose tissue. ${ }^{49,50,78}$

Ultrastructural morphological data have been combined to Energy Dispersive X-ray (EDX) microanalysis in biomedical research and diagnosis ${ }^{79}$ to detect asbestos fibers and metal contaminants in lung carcinomas, ${ }^{80,81}$ or to evaluate the biocompatibility of bone cements for reconstructive purposes, ${ }^{82}$ as well as to describe the effect of pollution on marine organisms in environmental research. ${ }^{83}$

Recently, TEM and atomic force microscopy have been used in a correlative approach, to characterize the byssus threads of Pinna nobilis ${ }^{84}$ or the protein globoids and starchy granules in the seeds of different cereals. ${ }^{85}$

Besides the use of electron microscopy as a high-resolution morphological support to light microscopy histochemistry, many authors directly applied ultrastructural cytochemistry and immunocytochemistry to various research fields.

A cytochemical approach using osmium ammine staining allowed to describe the DNA organization in the chromatin structure of mammalian nuclei. ${ }^{86}$ In several papers, diaminobenzidine photo-oxidation was applied to visualize fluorescent probes at TEM: by this approach, calcium ions were detected and located in the endoplasmic reticulum after staining with Mag-Fura 2 dye, ${ }^{87}$ the uptake and intracellular fate of different fluorescently-labelled nanoparticles was monitored, ${ }^{88,89}$ and the different subcellular compartments involved in the endocytosis routes were precisely described after labelling the plasma membrane with the fluorescent dye, PKH26. ${ }^{90}$ The possibility to combine diaminobenzidine photo-oxidation and gold immunolabelling was also demonstrated..$^{91}$

Ultrastructural immunocytochemistry has largely been used to visualize specific proteins in cultured cells, ${ }^{66,92-94}$ as well as in calcified tissues, ${ }^{47,68,95}$ in the nervous tissue, ${ }^{96,97}$ in the skeletal muscle, ${ }^{56,98}$ and in the gonads. ${ }^{99}$ Immunocytochemistry at TEM has been coupled to Field Emission in Lens Scanning Electron Microscope, ${ }^{100-102}$ and has been performed in samples prepared for SEM, too. ${ }^{103}$

\section{Concluding remarks}

It is therefore clear that electron microscopy not only has maintained its fundamental role in histochemical studies in a variety of, let's say, traditional research fields (cell and developmental biology, biomedicine, zoology), but has likewise proven to be useful in novel research areas such as nanotechnology and regenerative medicine. Moreover, the successful association of the ultrastructural approach with other powerful high-resolution techniques (e.g., X-ray microanalysis and atomic force microscopy) demonstrates the great versatility of electron microscopy, thus accounting for

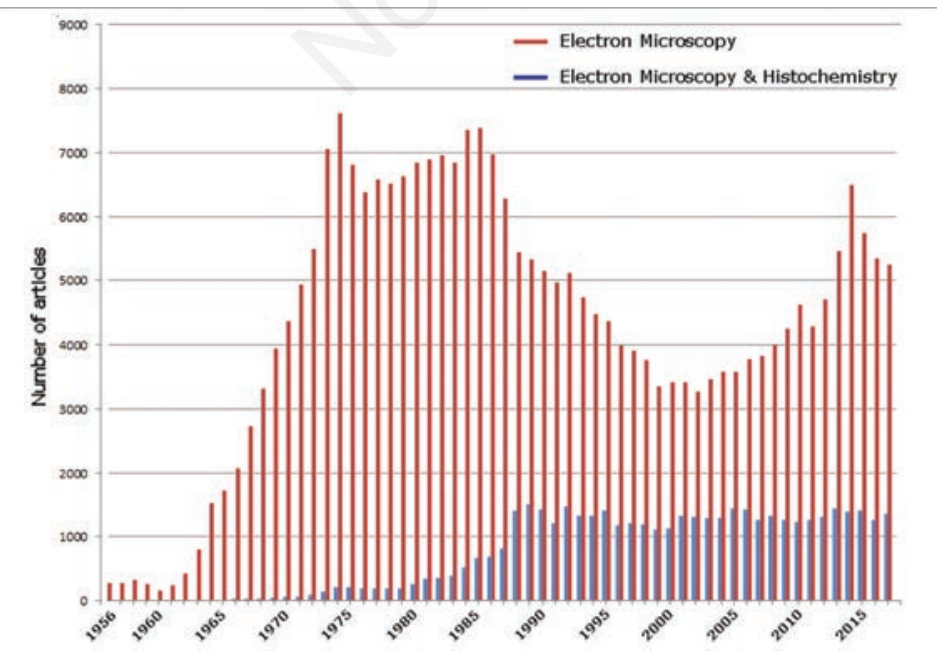

Figure 1. Number of scientific articles containing electron microscopy data published since 1956.

the increase of its utilization by scientists in recent years.

As much as super-resolution light microscopy, electron microscopy requires expensive equipment, highly qualified personnel and time-consuming protocols, which are all detrimental characteristics in the present research word ruled by the "publish or perish" imperative; despite this limit, these techniques are essential for biomedical research where the detection of single molecules needs to be associated to their precise location, at the subcellular (or even sub-organellar) level. ${ }^{10}$ Actually, to mechanistically understand the function of an organelle or a macromolecular complex, the composition and structure of its molecular components must be viewed in the frame of their spatial organization within the cell; thus, imaging molecules will continue to remain a crucial issue in biomedical research, in the years to come.

Electron microscopy will continue to be irreplaceable for ultrastructural morphology in basic and applied biomedical research: it still has better resolution than fluorescence super-resolution microscopy, and has the advantage to allow a direct visualization of both the membrane-bounded and cytosolic structural components of the cell, whereas in super-resolution microscopy all these structures are indirectly resolved through the labelling of their molecular components by fluorescent probes.

Correlative light and electron microscopy (CLEM) methods effectively integrate the advantages offered by fluorescence microscopy and electron microscopy: ${ }^{105-107}$ in fact, while light microscopy allows to screen relatively wide areas of the sample where multiple molecular species (proteins, carbohydrates, lipids and nucleic acids) may simultaneously be detected by specific labelling, electron microscopy makes it possible to spatially visualize both labeled and unlabeled structures at the highest resolution.

Nowadays, the application of CLEM and of refined ultrastructural histochemical techniques is giving back electron microscopy its central role in functional cell and tissue biology, as a really unique tool for high-resolution molecular biology in situ. ${ }^{108}$

\section{References}

1. Masters BR. History of the electron microscope in cell biology. In: Encyclopedia of Life Sciences (ELS). J. Wiley \& Sons: Chichester, 2009.

2. Guzzinati G, Altantzis T, Batuk M, De Backer A, Lumbeeck G, Samaee V, et 
al. Recent advances in transmission electron microscopy for materials science at the EMAT Lab of the University of Antwerp. Materials 2018;11;1304.

3. Barrnett RJ, Palade G. Applications of histochemistry to electron microscopy. Proceedings of the Gomori Symposium: Localization in Histochemistry, 8th Annual Meeting of the Histochemical Society, Baltimore, April 16, 1957.

4. Leduc EH, Bernhard W. Ultrastructural cytochemistry: Enzyme and Acid Hydrolysis of Nucleic Acids and Protein. J Biophys Biochem Cytol 1961;10:437-55.

5. Bernhard W, Tournier P. Ultrastructural cytochemistry applied to the study of virus infection. Cold Spring Harb Symp Quant Biol 1962;27:67-82.

6. Monneron A, Bernhard W. Fine structural organization of the interphase nucleus in some mammalian cells. J Ultrastruct Res 1969;27:266-88.

7. Powell MJ. Ultrastructural cytochemistry of the diaminobenzidine reaction in the aquatic fungus Entophlyctis variabilis. Arch Microbiol 1977;114: 123-36.

8. Deltour R, Gautier A, Fakan J. Ultrastructural cytochemistry of the nucleus in Zea mays embryos during germination. J Cell Sci 1979;40:43-62.

9. Yunge L, Benchimol S, Cantin M. Ultrastructural cytochemistry of atrial muscle cells. VII. radioautographic study of synthesis and migration of glycoproteins. J Mol Cell Cardiol 1979;11:375-88.

10. Horisberger $M$, Vonlanthen $M$. Fluorescent colloidal gold: a cytochemical marker for fluorescent and electron microscopy. Histochemistry 1979;64:115-8.

11. O'Brien M, Catovsky D, Costello C. Ultrastructural cytochemistry of leukaemic cells: characterization of the early small granules of monoblasts. $\mathrm{Br}$ J Haematol 1980;45:201-8.

12. Derenzini M, Viron A, PuvionDutilleul F. The Feulgen-like osmiumammine reaction as a tool to investigate chromatin structure in thin sections. J Ultrastruct Res 1982;80:13347.

13. Kurosawa H, Eguchi M, Sakakibara H, Takahashi H, Furukawa T. Ultrastructural cytochemistry of congenital basophilic leukemia. Am J Pediatr Hematol Oncol 1987;9:27-32.

14. Sundermann CA, Hussey RS. Ultrastructural Cytochemistry of Secretory Granules of Esophageal Glands of Meloidogyne incognita. J Nematol 1988;20:141-9.
15. Vorbrodt AW. Ultrastructural cytochemistry of blood-brain barrier endothelia. Prog Histochem Cytochem 1988;18:1-99.

16. Fakan S, Hughes ME. Fine structural ribonucleoprotein components of the cell nucleus visualized after spreading and high resolution autoradiography. Chromosoma 1989;98:242-9.

17. Derenzini M, Thiry M, Goessens G. Ultrastructural cytochemistry of the mammalian cell nucleolus. J Histochem Cytochem 1990;38:123756.

18. Malatesta M, Zancanaro C, Martin TE, Chan EK, Amalric F, Lührmann R, et al. Cytochemical and immunocytochemical characterization of nuclear bodies during hibernation. Eur J Cell Biol 1994;65:82-93.

19. Testillano PS, Gorab E, Risueño MC. A new approach to map transcription sites at the ultrastructural level. J Histochem Cytochem 1994;42:1-10.

20. Kopecny V, Biggiogera M, Pivko J, Grafenau P, Pavlok A, Malatesta M, et al. The cell nucleus in early bovine and caprine preimplantation embryos: fine structural cytochemistry and immunoelectron microscopy. Eur J Cell Biol 1996;70:361-72.

21. Riminucci M, Silvestrini G, Bonucci E, Fisher LW, Gehron Robey P, Bianco P. The anatomy of bone sialoprotein immunoreactive sites in bone as revealed by combined ultrastructural histochemistry and immunohistochemistry. Calcif Tissue Int 1995;57:277-84.

22. Ishizeki $K$, Nagano $H$, Nawa $T$. Features of the aperiodic microfibrils associated with mouse dental basement membrane demonstrated by ultrastructural histochemistry. J Anat 1990;173: 139-50.

23. Malatesta M, Mannello F, Luchetti F, Marcheggiani F, Condemi L, Papa S, et al. Prostate-specific antigen synthesis and secretion by human placenta: a physiological kallikrein source during pregnancy. J Clin Endocrinol Metab 2000;85:317-21.

24. Fakan S. Ultrastructural cytochemical analyses of nuclear functional architecture. Eur J Histochem 2004;48:5-14.

25. Vecchio L, Soldani C, Bottone MG, Malatesta M, Martin TE, Rothblum LI, et al. DADLE induces a reversible hibernation-like state in $\mathrm{HeLa}$ cells. Histochem Cell Biol 2006;125:193201.

26. Sathananthan AH, Nottola SA. Digital imaging of stem cells by electron microscopy. Methods Mol Biol 2007;407:21-41.

27. Orsini G, Ruggeri A Jr, Mazzoni A,
Papa V, Mazzotti G, Di Lenarda R, et al. Immunohistochemical identification of decorin and biglycan in human dentin: a correlative field emission scanning electron microscopy/transmission electron microscopy study. Calcif Tissue Int 2007;81:39-45.

28. Biggiogera M, Fakan S. Visualization of nuclear organization by ultrastructural cytochemistry. Methods Cell Biol 2008;88:431-49.

29. Rouquette J, Kalland KH, Fakan S. Visualisation of RNA by electron microscopic in situ hybridisation. Methods Mol Biol 2009;464:403-13.

30. Malatesta M, Meola G. Structural and functional alterations of the cell nucleus in skeletal muscle wasting: the evidence in situ. Eur J Histochem 2010; 54:e44.

31. Niedojadlo J, Perret-Vivancos C, Kalland KH, Cmarko D, Cremer T, van Driel R, et al. Transcribed DNA is preferentially located in the perichromatin region of mammalian cell nuclei. Exp Cell Res 2011;317:433-44.

32. Chemes HE. Ultrastructural analysis of testicular tissue and sperm by transmission and scanning electron microscopy. Methods Mol Biol 2013;927:321-48.

33. Pellicciari C, Giagnacovo M, Cisterna B, Costanzo M, Croce AC, Bottiroli G, et al. Ultrastructural detection of photosensitizing molecules by fluorescence photoconversion of diaminobenzidine. Histochem Cell Biol 2013;139: 863-71.

34. Philimonenko VV, Philimonenko AA, Šloufová I, Hrubý M, Novotný F, Halbhuber Z, et al. Simultaneous detection of multiple targets for ultrastructural immunocytochemistry. Histochem Cell Biol 2014;141:229-39.

35. Scassellati C, Costanzo M, Cisterna B, Nodari A, Galiè M, Cattaneo A, et al. Effects of mild ozonisation on gene expression and nuclear domains organization in vitro. Toxicol In Vitro 2017;44:100-110.

36. Costanzo M, Scolaro L, Berlier G, Marengo A, Grecchi S, Zancanaro C, et al. Cell uptake and intracellular fate of phospholipidic manganese-based nanoparticles. Int J Pharm 2016;508: 83-91.

37. Pellicciari C. Is there still room for novelty, in histochemical papers? Eur J Histochem 2016;60:2758.

38. Malatesta M. Transmission electron microscopy for nanomedicine: novel applications for long-established techniques. Eur J Histochem 2016;60: 2751.

39. Sun Q, Sun Y, Juzenas K. Immunogold scanning electron microscopy can reveal the polysaccharide architecture 
of xylem cell walls. J Exp Bot 2017; 68:2231-44.

40. Pellicciari C. Histochemistry as an irreplaceable approach for investigating functional cytology and histology. Eur J Histochem 2013;57:e41.

41. Pellicciari C. Histochemistry today: Detection and location of single molecules. Eur J Histochem 2017;61(4):2785.

42. Galbraith CG, Galbraith JA. Super-resolution microscopy at a glance. J Cell Sci 2011;124:1607-11.

43. Andrew M, Sydor AM, Czymmek KJ, Puchner EM, Mennella V. SuperResolution microscopy: from single molecules to supramolecular assemblies. Trends Cell Biol 2015;25:730-48.

44. Vicidomini G, Bianchini P, Diaspro A. STED super-resolved microscopy. Nat Methods 2018;15:173-82.

45. Sahl SJ, Hell SW, Jakobs S. Fluorescence nanoscopy in cell biology. Nat Rev Mol Cell Biol 2017;18: 685-701.

46. Baddeley D, Bewersdorf J. Biological insight from Super-Resolution Microscopy: What we can learn from localization-based images. Annu Rev Biochem 2018;87:965-89.

47. Orsini G, Ruggeri A, Mazzoni A, Nato F, Falconi M, Putignano A, et al. Immunohistochemical localization of dentin matrix protein 1 in human dentin. Eur J Histochem 2008;52:215-20.

48. Teti G, Salvatore V, Ruggeri A, Manzoli L, Gesi M, Orsini G, et al. In vitro reparative dentin: a biochemical and morphological study. Eur J Histochem 2013;57:e23.

49. Sbarbati A, Accorsi D, Benati D, Marchetti L, Orsini G, Rigotti G, et al. Subcutaneous adipose tissue classification. Eur J Histochem 2010;54:e48.

50. Panettiere P, Accorsi D, Marchetti L, Minicozzi AM, Orsini G, Bernardi P, et al. The trochanteric fat pad. Eur J Histochem 2011;55:e16.

51. Miko M, Danišovič L, Majidi A, Varga I. Ultrastructural analysis of different human mesenchymal stem cells after in vitro expansion: a technical review. Eur J Histochem 2015;59:2528.

52. Costanzo M, Boschi F, Carton F, Conti G, Covi V, Tabaracci G, et al. Low ozone concentrations promote adipogenesis in human adipose-derived adult stem cells. Eur J Histochem 2018;62:2969.

53. Curzi D, Salucci S, Marini M, Esposito F, Agnello L, Veicsteinas A, et al. How physical exercise changes rat myotendinous junctions: an ultrastructural study. Eur J Histochem 2012; 56:e19.

54. Curzi D, Lattanzi D, Ciuffoli S,
Burattini S, Grindeland RE, Edgerton VR et al. Growth hormone plus resistance exercise attenuate structural changes in rat myotendinous junctions resulting from chronic unloading. Eur $\mathrm{J}$ Histochem 2013;57:e37.

55. Perdoni F, Malatesta M, Cardani R, Giagnacovo M, Mancinelli E, Meola $\mathrm{G}$, et al. RNA/MBNL1-containing foci in myoblast nuclei from patients affected by myotonic dystrophy type 2: an immunocytochemical study. Eur J Histochem 2009;53:151-8.

56. Giagnacovo M, Cardani R, Meola G, Pellicciari C, Malatesta M. Routinely frozen biopsies of human skeletal muscle are suitable for morphological and immunocytochemical analyses at transmission electron microscopy. Eur J Histochem 2010;54:e31.

57. Boncompagni E, Gini E, Ferrigno A, Milanesi G, Gringeri E, Barni S, et al. Decreased apoptosis in fatty livers submitted to subnormothermic machineperfusion respect to cold storage. Eur J Histochem 2011;55:e40.

58. Polakovičová $\mathrm{S}$, Csöbönyeiová $\mathrm{M}$, Filova B, Borovský M, Maršík L, Kvasilová A, et al. Merkel-like cell distribution in the epithelium of the human vagina. An immunohistochemical and TEM study. Eur J Histochem 2018;62:2836.

59. Khalili MA, Maione M, Palmerini MG, Bianchi S, Macchiarelli G, Nottola SA. Ultrastructure of human mature oocytes after vitrification. Eur J Histochem 2012;56:e38.

60. Monti M, Calligaro A, Behr B, Rejo Pera R, Redi CA, Wossidlo M. Functional topography of the fully grown human oocyte. Eur J Histochem 2017;61:2769.

61. Boháč M, Danišovič L, Koller J, Dragúňová J, Varga I. What happens to an acellular dermal matrix after implantation in the human body? A histological and electron microscopic study. Eur J Histochem 2018;62:2873.

62. Visonà $\mathrm{SD}$, Benati $\mathrm{D}$, Monti $\mathrm{MC}$, Galiè M, Andrello L, Frontini A, et al. Diagnosis of sudden cardiac death due to early myocardial ischemia: An ultrastructural and immunohistochemical study. Eur J Histochem 2018;62:2866.

63. Casadei L, Vallorani L, Gioacchini AM, Guescini M, Burattini S, D'Emilio $\mathrm{A}$, et al. Proteomics-based investigation in C2C12 myoblast differentiation. Eur J Histochem 2009;53:e31.

64. Markelic M, Velickovic K, Golic I, Otasevic V, Stancic A, Jankovic A, et al. Endothelial cell apoptosis in brown adipose tissue of rats induced by hyperinsulinaemia: the possible role of TNF- $\alpha$. Eur J Histochem 2011;55:e34.

65. Fassina L, Magenes G, Inzaghi A, Palumbo S, Allavena G, Miracco C, et al. AUTOCOUNTER, an ImageJ JavaScript to analyze LC3B-GFP expression dynamics in autophagyinduced astrocytoma cells. Eur J Histochem 2012;56:e44.

66. Costanzo M, Cisterna B, Vella A, Cestari T, Covi V, Tabaracci G, et al. Low ozone concentrations stimulate cytoskeletal organization, mitochondrial activity and nuclear transcription. Eur J Histochem 2015;59:2515.

67. Golic I, Velickovic K, Markelic M, Stancic A, Jankovic A, Vucetic M, et al. Calcium-induced alteration of mitochondrial morphology and mitochondrial-endoplasmic reticulum contacts in rat brown adipocytes. Eur J Histochem 2014;58:2377.

68. Bradaschia-Correa V, Barrence FA, Ferreira LB, Massa LF, Arana-Chavez VE. Effect of alendronate on endochondral ossification in mandibular condyles of growing rats. Eur J Histochem 2012;56:e24.

69. Escobar Sánchez ML, Echeverría Martínez OM, Vázquez-Nin GH. Immunohistochemical and ultrastructural visualization of different routes of oocyte elimination in adult rats. Eur J Histochem 2012;56:e17.

70. Longo M, Boiani M, Redi CA, Monti M. Cytoplasmic lattices are not linked to mouse 2-cell embryos developmental arrest. Eur J Histochem 2018;62: 2972.

71. Acosta M, Filippa V, Mohamed F. Folliculostellate cells in pituitary pars distalis of male viscacha: immunohistochemical, morphometric and ultrastructural study. Eur J Histochem 2010;54:e1.

72. Meyer W, Kacza J, Hornickel IN, Schoennagel B. Immunolocalization of succinate dehydrogenase in the esophagus epithelium of domesticated mammals. Eur J Histochem 2013;57:e18.

73. Zhang H, Guo X, Zhong S, Ge T, Peng $\mathrm{S}, \mathrm{Yu} \mathrm{P}$, et al. Heterogeneous vesicles in mucous epithelial cells of posterior esophagus of Chinese giant salamander (Andrias davidianus). Eur J Histochem 2015;59:2521.

74. Zhang H, Yu P, Zhong S, Ge T, Peng S, Zhou Z, et al. Gliocyte and synapse analyses in cerebral ganglia of the Chinese mitten crab, Eriocheir sinensis: ultrastructural study. Eur J Histochem 2016;60:2655.

75. Costanzo M, Carton F, Marengo A, Berlier G, Stella B, Arpicco S, et al. Fluorescence and electron microscopy to visualize the intracellular fate of 
nanoparticles for drug delivery. Eur J Histochem 2016;60:2640.

76. Carton F, Calderan L, Malatesta M. Incubation under fluid dynamic conditions markedly improves the structural preservation in vitro of explanted skeletal muscles. Eur J Histochem 2017;61:2862.

77. Dall'Oca C, Maluta T, Cavani F, Morbioli GP, Bernardi P, Sbarbati A, et al. The biocompatibility of porous vs non-porous bone cements: a new methodological approach. Eur J Histochem 2014;58:2255.

78. Conti G, Bertossi D, Dai Pré E, Cavallini C, Scupoli MT, Ricciardi G, et al. Regenerative potential of the Bichat fat pad determined by the quantification of multilineage differentiating stress enduring cells. Eur J Histochem 2018;62:2900.

79. Scimeca M, Bischetti S, Lamsira HK, Bonfiglio R, Bonanno E. Energy Dispersive X-ray (EDX) microanalysis: A powerful tool in biomedical research and diagnosis. Eur J Histochem 2018;62:2841.

80. Scimeca M, Orlandi A, Terrenato I, Bischetti S, Bonanno E. Assessment of metal contaminants in non-small cell lung cancer by EDX microanalysis. Eur J Histochem 2014;58:2403.

81. Scimeca M, Pietroiusti A, Milano F, Anemona L, Orlandi A, Marsella LT, et al. Elemental analysis of histological specimens: a method to unmask nano asbestos fibers. Eur J Histochem 2016; 60:2573.

82. Dall'Oca C, Maluta T, Micheloni GM, Cengarle M, Morbioli G, Bernardi P, et al. The biocompatibility of bone cements: progress in methodological approach. Eur J Histochem 2017; 61:2673.

83. Frontalini F, Curzi D, Giordano FM, Bernhard JM, Falcieri E, Coccioni R. Effects of lead pollution on Ammonia parkinsoniana (foraminifera): ultrastructural and microanalytical approaches. Eur J Histochem 2015; 59:2460

84. Diana A, Reguzzoni M, Congiu T, Rescigno A, Sollai F, Raspanti M. The byssus threads of Pinna nobilis: A histochemical and ultrastructural study. Eur J Histochem 2017;61:2779.

85. Antonini E, Zara C, Valentini L, Gobbi P, Ninfali P, Menotta M. Novel insights into pericarp, protein body globoids of aleurone layer, starchy granules of three cereals gained using atomic force microscopy and environmental scanning electronic microscopy. Eur J Histochem 2018;62:2869.

86. Derenzini M, Olins AL, Olins DE.
Chromatin structure in situ: the contribution of DNA ultrastructural cytochemistry. Eur J Histochem 2014; 58:2307.

87. Poletto V, Galimberti V, Guerra G, Rosti V, Moccia F, Biggiogera M. Fine structural detection of calcium ions by photoconversion. Eur J Histochem 2016;60:2695.

88. Malatesta M, Giagnacovo M, Costanzo M, Conti B, Genta I, Dorati R, et al. Diaminobenzidine photoconversion is a suitable tool for tracking the intracellular location of fluorescently labelled nanoparticles at transmission electron microscopy. Eur J Histochem 2012; 56:e20.

89. Malatesta M, Grecchi S, Chiesa E, Cisterna B, Costanzo M, Zancanaro C. Internalized chitosan nanoparticles persist for long time in cultured cells. Eur J Histochem 2015;59:2492.

90. Grecchi S, Malatesta M. Visualizing endocytotic pathways at transmission electron microscopy via diaminobenzidine photo-oxidation by a fluorescent cell-membrane dye. Eur J Histochem 2014;58:2449.

91. Malatesta M, Zancanaro C, Costanzo M, Cisterna B, Pellicciari C. Simultaneous ultrastructural analysis of fluorochrome-photoconverted diaminobenzidine and gold immunolabelling in cultured cells. Eur J Histochem 2013;57:e26.

92. Perdoni F, Malatesta M, Cardani R, Giagnacovo M, Mancinelli E, Meola $\mathrm{G}$, et al. RNA/MBNL1-containing foci in myoblast nuclei from patients affected by myotonic dystrophy type 2 : an immunocytochemical study. Eur J Histochem 2009;53:151-8.

93. Malatesta M, Giagnacovo M, Renna LV, Cardani R, Meola G, Pellicciari C. Cultured myoblasts from patients affected by myotonic dystrophy type 2 exhibit senescence-related features: ultrastructural evidence. Eur J Histochem 2011;55:e26.

94. Zhao Y, Huang H, Jiang Y, Wei H, Liu $\mathrm{P}$, Wang $\mathrm{W}$, et al. Unusual localization and translocation of TRPV4 protein in cultured ventricular myocytes of the neonatal rat. Eur J Histochem 2012; 56:e32.

95. Nanci A, Wazen R, Nishio C, Zalzal SF. Immunocytochemistry of matrix proteins in calcified tissues: functional biochemistry on section. Eur $\mathrm{J}$ Histochem 2008;52:201-14.

96. Natale G, Pompili E, Biagioni F, Paparelli S, Lenzi P, Fornai F. Histochemical approaches to assess cell-to-cell transmission of misfolded proteins in neurodegenerative diseases.
Eur J Histochem 2013;57:e5.

97. Kálmán M, Oszwald E, Adorján I. Appearance of $\beta$-dystroglycan precedes the formation of glio-vascular end-feet in developing rat brain. Eur $\mathrm{J}$ Histochem 2018;62:2908.

98. Malatesta M, Perdoni F, Muller S, Zancanaro C, Pellicciari C. Nuclei of aged myofibres undergo structural and functional changes suggesting impairment in RNA processing. Eur J Histochem 2009;53:97-106.

99. Escobar ML, Echeverría OM, García G, Ortíz R, Vázquez-Nin GH. Immunohistochemical and ultrastructural study of the lamellae of oocytes in atretic follicles in relation to different processes of cell death. Eur J Histochem 2015;59:2535.

100. Salucci S, Burattini S, Falcieri E, Gobbi P. Three-dimensional apoptotic nuclear behavior analyzed by means of Field Emission in Lens Scanning Electron Microscope. Eur J Histochem 2015;59:2539.

101. Martini D, Trirè A, Breschi L, Mazzoni A, Teti G, Falconi M, et al. Dentin matrix protein 1 and dentin sialophosphoprotein in human sound and carious teeth: an immunohistochemical and colorimetric assay. Eur J Histochem 2013;57:e32.

102. Ruggeri A, Orsini G, Mazzoni A, Nato F, Papa V, Piccirilli M, et al. Immunohistochemical and biochemical assay of versican in human sound predentine/dentine matrix. Eur J Histochem 2009;53:125-33.

103. Nanci A, Wazen R, Nishio C, Zalzal SF. Immunocytochemistry of matrix proteins in calcified tissues: functional biochemistry on section. Eur J Histochem 2008;52:201-14.

104. Pellicciari C, Biggiogera $M$. Histochemistry of single molecule: Methods and protocols. Methods Mol Biol 1560. Humana Press, New York: 2017.

105. Spiegelhalter C, Laporte JF, Schwab Y. Correlative light and electron microscopy: from live cell dynamic to 3D ultrastructure. Methods Mol Biol 2014;1117:485-501.

106. de Boer P, Hoogenboom JP, Giepmans BNG. Correlated light and electron microscopy: ultrastructure lights up! Nat Methods 2015;12:503-13.

107. Kobayashi S, Iwamoto M, Haraguchi $\mathrm{T}$. Live correlative light-electron microscopy to observe molecular dynamics in high resolution. Microscopy 2016;65:296-308.

108. Meschini S. Correlative Microscopy in Life and Materials Sciences. Eur J Histochem 2017;61(s4):1-8. 